\title{
BOEKBESPREKINGEN
}

\section{Praktijkgericht juridisch onderzoek ${ }^{*}$}

\author{
Yvonne Denissen-Visscher
}

G.A.F.M. van Schaaijk, Praktijkgericht juridisch onderzoek, Den Haag: Boom Juridische uitgevers 2011

Deze recensie gaat in op de methode voor praktijkgericht juridisch onderzoek van mr. G.A.F.M. van Schaaijk en op de ervaringen die mijn studenten aan de Hogere Juridische Opleiding van Saxion en ik hiermee hebben opgedaan.

Onderzoek wordt ook in het hoger beroepsonderwijs steeds meer een vast onderdeel van het curriculum. Het gaat dan om praktijkgericht onderzoek waarbij de kennis die de student genereert bijdraagt aan de oplossing van een vraagstuk uit de praktijk. Hierbij kan de student prima gebruikmaken van sociaalwetenschappelijke en natuurwetenschappelijke onderzoeksmethoden. Bij hbo-opleidingen met een sterk juridische component zoals HBO Recht en HJO (Hogere Juridische Opleiding) doet zich echter een probleem voor. Want empirische onderzoeksmethoden zoals het causaal veldmodel en het verzamelen van data voor een datamatrix zijn niet geschikt voor het vinden van een antwoord op een juridisch vraagstuk. Neem bijvoorbeeld een onderzoek in opdracht van een voetbalclub naar het voorkomen van aansprakelijkheid voor de schade als gevolg van vernielingen die tijdens een uitwedstrijd worden aangericht door de eigen leden/supporters in het stadion van de gastclub. Natuurlijk zijn de supporters zelf aansprakelijk, maar gaat de uitspelende club altijd vrijuit? Voor aansprakelijkheid geldt de voorwaarde van de causaliteit: tussen de oorzaak en de schade moet een verband bestaan. Pas als dit is vastgesteld ontstaat de verplichting om de schade te betalen, tenminste als ook is voldaan aan de andere voorwaarden voor een onrechtmatige daad. Het is bij dit onderzoek echter niet logisch om de causaliteit vast te stellen met een causaal veldmodel. En het vinden en interpreteren van de toepasselijke wetsartikelen aan de hand van de memorie van toelichting is niet te vergelijken met het verzamelen van data voor de datamatrix. Ook rechtswetenschappelijk onderzoek waarbij het recht zelf wordt onderzocht schiet hier echter tekort. Het praktijkgericht juridisch onderzoek in bovenstaand voorbeeld moet zich immers ook richten op de (niet-juridische) maatregelen waardoor aansprakelijkheid kan worden voorkomen. Hiervan moet tenminste de werkzaamheid worden onderzocht.

Juridisch onderzoek in het hbo is per definitie praktijkgericht juridisch onderzoek en dit vraagt om een speciale methode. Bij het lectoraat Gebiedsontwikkeling en recht van het Kenniscentrum leefomgeving van Saxion hebben we ons vorig jaar

* Mr. Yvonne Denissen-Visscher is docent recht en senior onderzoeker bij het Lectoraat Gebiedsontwikkeling en recht van het Kenniscentrum leefomgeving van Saxion. 
verdiept in praktijkgericht juridisch onderzoek. Omdat niet direct duidelijk was wat juridisch onderzoek in het hbo zou moeten of kunnen inhouden en welke vaardigheden hierbij van een student en docent werden verlangd, hebben we op 15 juni 2010 in Deventer het congres 'Juridisch onderzoek in het hbo' georganiseerd. Daar gaf mevrouw G.A.F.M. van Schaaijk een workshop over de didactische methode die zij voor praktijkgericht juridisch onderzoek had ontwikkeld. Dit was een eyeopener voor velen. Inmiddels is haar boek Praktijkgericht juridisch onderzoek verschenen en heb ik de daarin beschreven methode toegepast bij Saxion in het tweede jaar van het curriculum van HJO. Ik zal hierna eerst ingaan op de methode van Van Schaaijk en daarna mijn ervaringen en die van de studenten beschrijven.

In Praktijkgericht juridisch onderzoek heeft Van Schaaijk de bestaande onderzoeksmethoden op een verrassend eenvoudige manier geïntegreerd. Enerzijds wordt het praktijkprobleem, of beter gezegd de oplossing hiervan, getoetst aan het recht. Anderzijds worden de effecten van een juridische oplossing onderzocht. De kapstok hiervoor bestaat uit twee vragen die de kern van het praktijkgericht juridisch onderzoek vormen: mag dat en/of werkt dit? Met andere woorden: voldoet de praktische oplossing voor het praktijkprobleem aan de juridische normen en/ of is de juridische oplossing efficiënt? Laten we dit eens toepassen op een veelbesproken praktijkprobleem: de legitimatie van het vastbinden van psychiatrisch patiënten zoals de veelbesproken jongen Brandon. Dan zouden we de volgende onderzoeksvraag kunnen formuleren: onder welke voorwaarden is het vastketenen van psychiatrisch patiënten juridisch gezien toegestaan? Het gaat hier om een mag dat?-vraag en het onderzoek richt zich op de vraag of de praktische oplossing (het beperken van de bewegingsvrijheid) voldoet aan de juridische normen. De werkt dit?-vraag zouden we kunnen toepassen op het wetsvoorstel met betrekking tot de boete voor langstudeerders. De onderzoeksvraag zou dan kunnen luiden: is het opleggen van een bestuurlijke boete aan studenten die langer dan de gebruikelijke studieduur studeren effectief? Anders gezegd: werkt de juridische maatregel voor deze groep studenten? Om deze vragen te kunnen beantwoorden moet zowel het recht (de juridische normen c.q. de juridische maatregel) als de praktijk (het vastketenen van patiënten c.q. het effect van de boete) worden onderzocht. Soms kan in een onderzoek zowel de mag dat?-vraag als de werkt dit?-vraag worden gesteld. Bijvoorbeeld: in hoeverre is het opleggen van een bestuurlijke boete aan langstudeerders toegestaan en effectief? In een dergelijk praktijkgericht juridisch onderzoek wordt onderzocht of de wet het opleggen van een boete legitimeert (mag dat?) en of deze juridische maatregel het beoogde effect heeft in de praktijk (werkt dit?).

De twee typen vraagstelling vormen het onderzoeksmodel voor praktijkgericht juridisch onderzoek. Het eigenlijke onderzoek begint met de voorbereidende fase waarin de student zich oriënteert op de opdracht en het onderwerp, een probleembeschrijving en een centrale vraag formuleert en een onderzoeksopzet beschrijft met deelvragen en onderzoeksstrategieën. Vervolgens vindt de uitvoering van het onderzoek plaats waarbij zowel het recht als de praktijk voorwerp is 
van onderzoek. Hierin onderscheidt dit model zich van de sociaalwetenschappelijke, natuurwetenschappelijke en rechtswetenschappelijke onderzoeksmethode die de focus op een van beide onderzoeksobjecten richten. Een belangrijk element is ook het argumenteren en concluderen om te komen tot een beredeneerd antwoord op de centrale vraag. Argumenteren is nodig bij praktijkgericht juridisch onderzoek omdat het recht vraagt om interpretatie van normen, wat wezenlijk iets anders is dan het interpreteren en verwerken van de verzamelde data. Ten slotte volgt het schrijven van het PJO-rapport waarin de student de gehanteerde onderzoeksmethode verantwoordt en waarbij hij moet voldoen aan de verschillende eisen die worden gesteld aan het citeren en vermelden van juridische en andere bronnen. Het verrichten van onderzoek is in beginsel een doorlopend proces, maar het komt dikwijls voor dat de student even moet terugschakelen naar een eerder stadium. Dit is bij praktijkgericht juridisch onderzoek niet anders dan bij andere vormen van onderzoek.

Tot zover de onderzoeksmethode, maar wat zijn nu de ervaringen van de studenten? Mij is opgevallen dat de meeste studenten in het begin een drempel over moeten. Het vinden van een onderwerp dat zich leent voor praktijkgericht juridisch onderzoek is niet eenvoudig als je nog niet precies weet wat een dergelijk onderzoek inhoudt. En dat leer je pas als je met het onderwerp aan de slag gaat en het onderzoek gaat voorbereiden. Het begin moet dus zeker niet te abstract zijn. Een klein punt van kritiek op de opzet van het boek is dat het eerste hoofdstuk in vogelvlucht en weliswaar met voorbeelden het onderzoeksmodel beschrijft, maar dat de student geen concreet beeld krijgt hoe een praktijkgericht juridisch onderzoek eruit zou kunnen zien. Dat zal de docent dus moeten uitleggen en dat is niet eenvoudig als deze zelf (nog) onvoldoende inzicht heeft in de onderzoeksmethode en in de inhoud en opzet van een praktijkgericht juridisch onderzoek. Zoals gezegd hebben studenten door het gebrek aan inzicht moeite om een onderwerp te vinden dat zich leent voor praktijkgericht juridisch onderzoek. Velen zoeken houvast bij de hun bekende casusoplossing, waardoor het onderwerp beperkt blijft tot een individueel geval waarin een concreet juridisch advies moet worden gegeven. Het vraagt van de docent een extra inspanning om studenten verder en vooral breder te laten kijken zodat zij zich gaan oriënteren op een probleem uit de praktijk waarbij de kennis die zij met hun onderzoek genereren kan bijdragen aan een oplossing. Maar als de studenten eenmaal de drempel van het onderwerp over zijn dan gaat er een wereld voor hen open. Het boek is zeer toegankelijk geschreven en de verschillende stadia van het onderzoek en de activiteiten van de onderzoeker worden duidelijk toegelicht. Het schematisch overzicht vóór in het boek geeft de stadia en activiteiten in één oogopslag weer en helpt de studenten om het overzicht te bewaren. Wanneer studenten de in het boek beschreven onderzoeksactiviteiten wekelijks toepassen op hun eigen onderzoeksonderwerp dan creëren zij voor zichzelf een overzichtelijk geheel dat hun inzicht geeft in de opzet, inhoud en structuur van een praktijkgericht juridisch onderzoek. Het geven van feedback op de individuele prestaties vergt veel tijd, maar het loont de moeite. Het door de studenten zelf opgezette onderzoek vormt voor hen een handige leidraad voor onderzoeken die zij later in hun studie zullen uitvoeren. Het volgen van deze 
methode is tevens een uitstekende voorbereiding op het verrichten van een praktijkgericht juridisch afstudeeronderzoek. Naar mijn mening is de methode van Van Schaaijk niet alleen een eyeopener maar een echte eyecatcher. 